\title{
Natural infection of the redclaw crayfish Cherax quadricarinatus with presumptive spawner-isolated mortality virus
}

\author{
Leigh Owens*, Catriona McElnea \\ Department of Microbiology and Immunology, PO James Cook University, Townsville, Queensland 4811, Australia
}

\begin{abstract}
Crayfish farmers reported reduced tolerance of stress in specimens of Cherax quadricarinatus, which were formerly robust crayfish. Furthermore, one farmer reported a large reduction in yield with final harvest only equaling the stocking weight. Upon trapping, one-third of the crayfish regularly died overnight and a further one-third died on the sorting tray during sexing of juveniles ( $\sim 3$ mo old). Histopathological examination revealed very light ( 1 or 2 cells per section) infections with Cherax giardiavirus and sometimes mild atrophy of hepatopancreatic cells. Gene probe analysis with a DIG-labeled spawner-isolated mortality virus (SMV) probe demonstrated extensive positive signals in nuclei of many tissues. The hepatopancreas, the midgut, glands associated with the midgut, the epithelium of seminal ducts and follicle cells surrounding oocytes gave the strongest positive signals. Nuclei of the heart, haemocytes, connective tissue and subcutis gave positive signals in some individuals. Although signals were intense and extensive, cytolysis of infected cells was very limited. The possibility of cross infections of SMV between prawns and freshwater crayfish is of international quarantine significance.
\end{abstract}

KEY WORDS: Freshwater crayfish · Cherax quadricarinatus . Spawner-isolated mortality virus - Mortalities

Crayfish farming in Australia is a slowly developing aquaculture industry that was worth $\$$ A 3.5 million in 1997 (O'Sullivan 1998). The crayfish Cherax quadricarinatus industry has been relatively free of epizootic disease even though quite a few potential pathogens and even serious primary pathogens exist (Edgerton et al. 1995, Tan 1998). In northern Queensland, sequential surveys in 1992 and 1996 have shown a trend towards less healthy stocks over that period (Edgerton \& Owens 1999j. Rickettsia have been identified as a likely cause of serious mortalities (Tan 1998) as once individuals become infected, they are always over-

\footnotetext{
•E-mail: leigh.owens@jcu.edu.au
}

whelmed. While increasing in prevalence, Cherax bacilliform virus (CBV) has not been associated with increased overt mortalities. Cherax giardiavirus-like virus (CGV) has remained at previous levels and only been associated with mortalities in hatcheries (Edgerton et al. 1994). However, Owens \& Edgerton (1997) proposed in 1995 that 'Possibly the most important area of study for crayfish disease is the effect of pathogenic penaeid viruses on crayfish'.

In 1997-1998, crayfish from some farms were noted to be much more susceptible to capture and transport stress than previously. Practices that had previously caused no mortality were apparently leading to $60-100 \%$ mortality over a 2 wk period. One farmer was concerned enough to seek advice. This note describes the histopathological investigation of the crayfish from that farm and the discovery of spawner-isolated mortality virus (SMV), formerly known only from penaeid prawns.

Materials and methods. Processing of specimens: Twelve crayfish (10 moribund and 2 healthy) were fixed at the farm in Davidson's fixative by injection and immersion for $24 \mathrm{~h}$, after which specimens were transferred to $70 \%$ ethanol for subsequent storage (Bell \& Lightner 1988). Following fixation, specimens were processed and embedded as described by Culling et al. (1985). Sections of $5 \mu \mathrm{m}$ were cut and stained with haemotoxylin and eosin (Culling et al. 1985). For in situ hybridisation, $5 \mu \mathrm{m}$ sections were adhered to silanetreated (3-aminopropyltriethoxy-silane) (Sigma) glass slides and left for $1 \mathrm{~h}$ at $60^{\circ} \mathrm{C}$.

Hybridisation: The tissue sections were probed only with the gene probe for SMV developed by Owens et al. (1998). The in situ hybridisation method used was based on that described by Rolighed \& Lindeberg (1996) with some modifications. Briefly, tissue sections were deparaffinised through xylene, washed several times in ethanol, rehydrated in distilled water and 
finally equilibrated in TNE $(50 \mathrm{mM}$ Tris- $\mathrm{HCl} \mathrm{pH} 7.4$ $10 \mathrm{mM} \mathrm{NaCl}, 1 \mathrm{mM}$ EDTA) buffer. Tissues were then made permeable to the probe by digestion with proteinase $\mathrm{K} 100 \mu \mathrm{g} \mathrm{ml}^{-1}$ at 37 to $56^{\circ} \mathrm{C}$ for $10 \mathrm{~min}$. Digestion was stopped by addition of glycine to a final concentration of $0.2 \%$ weight/volume (w/v) in TNE buffer. Tissues were then stablised in $0.4 \%$ paraformaldehyde for $5 \mathrm{~min}$ at $4^{\circ} \mathrm{C}$. This was followed by 2 washes in double distilled water for $5 \mathrm{~min}$, after which tissues were air dried for $5 \mathrm{~min}$. Probe was then applied at a concentration of $1 \mathrm{ng} \mathrm{H}^{-1}$ in hybridisation buffer $150 \%$ formamide, $5 \%$ dextran sulphate, $0.5 \mathrm{mg} \mathrm{ml}^{-1}$ sperm DNA, Denhardt's solution, $4 \times \mathrm{SSC}(0.15 \mathrm{M} \mathrm{NaCl}$, $0.015 \mathrm{M}$ sodium citrate at $\mathrm{pH} 7.0$ ) and a coverslip applied. Tissue and probe DNA was denatured simultaneously at $95^{\circ} \mathrm{C}$ for $8 \mathrm{~min}$. Slides were immediately quenched on ice for $1 \mathrm{~min}$ and hybridised at $25^{\circ} \mathrm{C}$ overnight. Nonspecifically bound probe was removed by washing in $2 \times \mathrm{SSC}$ twice for $5 \mathrm{~min}$ at room temperature and once in $0.1 \times \mathrm{SSC}$ at $37^{\circ} \mathrm{C}$. Detection of bound probe was carried out according to the protocol described by Durand et al. (1996) with colour development carried out overnight. Tissues were counterstained with $0.5 \%$ aqueous Bismarck brown for $30 \mathrm{~s}$ and mounted with Dako Permamount.

Results. Discussions with the farmer suggested that crayfish arriving from other farms for growing and reselling and those that were sent to market were largely dying over 2 wk after transportation. The farmer further reported a large reduction in yield, with the weight of crayfish at final harvest equaling only the weight of crayfish used for stocking. Normally, $100 \mathrm{~kg}$ of stocked juveniles would have produced between 1 and 3 tonnes. Upon trapping of 3 mo old juvenile
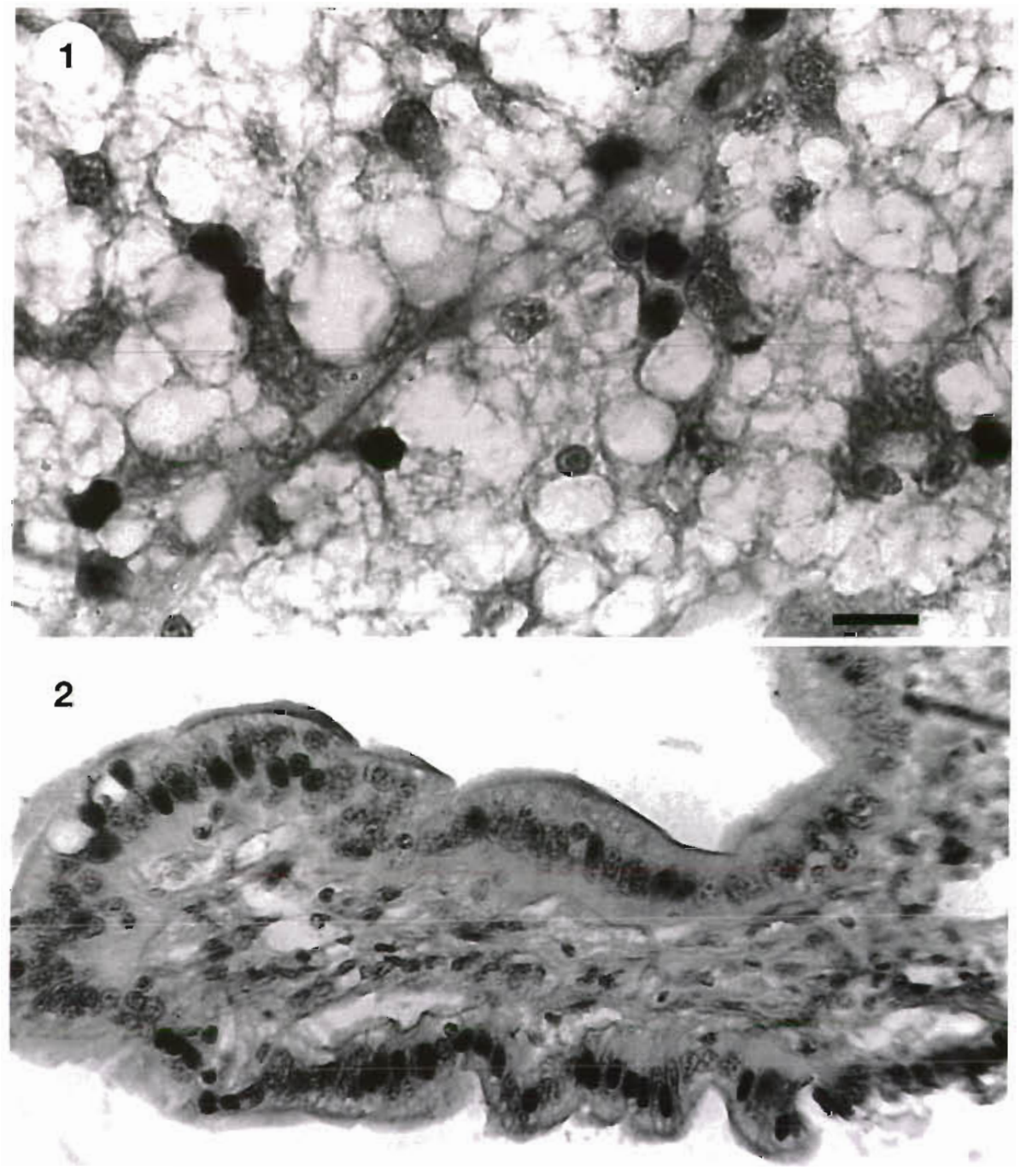

Fig. 1. Cherax quadricarinatus. Hepatopancreas of a moribund crayfish stained with the DIG-labeled gene probe for SMV. The nuclei that appear black in the photomicrograph stained dark purple to black, indicating a strong in situ hybridization reaction. Other nuclei that appear gray in the photomicrograph stained yellow with the Bismark brown counterstain. Scale bar $=$ $32 \mu \mathrm{m}$

Fig. 2. Cherax quadricarinatus. Junction of the foregut and midgut of a moribund crayfish. Note the presence of negatively stained nuclei (gray) adjacent foci of strongly positive nuclei (black) Note also the lack of any apparent pathology in the cells with the positive nuclei and how it would be difficult to distinguish between them and other cells without in situ hybridization. Scale bar $=39 \mu \mathrm{m}$ 
crayfish for sexing, one-third of the individuals would die overnight in the traps and a further one-third would die on the sorting tray during the sexing process.

The crayfish presented no external clinical signs associated with known diseases. There were no melanised appendages, black spots, epicommensal fouling, physical abrasions, or colour changes. In fact, the crayfish had superb natural coloration.

Histopathological examination revealed very light ( 1 or 2 cells per section) infections with Cherax giardiavirus at a prevalence of $17 \%(2 / 12)$. Three of the crayfish had haemocytic enteritis in the foregut and the proximal portion of the midgut. Eight crayfish possibly had mild atrophy of the hepatopancreatic cells leading to a larger lumenal area in the hepatopancreatic tubules. This suggested a mild starvation. There was a total lack of Cherax bacilliform virus, necrotic foci, haemocytic granulomas, Psorospermium spores, colonies of bacteria and rickettsial microcolonies.

In situ hybridisation with a DIG-labeled SMV probe gave positive signals in the nuclei of many organs of moribund individuals. These were evident as light to dark purple or black stained nuclei against the yellow counterstain. In moribund crayfish, strong positive reactions were seen in the hepatopancreas (Fig. 1), midgut (Fig. 2), glands associated with the midgut (Fig. 3), the epithelium of seminal ducts (Fig. 4) and follicle cells surrounding oocytes (Fig. 5). Heart cells (Fig. 6), haemocytes, connective tissue and subcutis stained in some individual crayfish. The hepatopancreas of a crayfish from a pond that was producing quite well was tested with the same probe but no positive reaction was seen (Fig. 7). In crayfish with haemocytic enteritis, there was weak positive staining within haemocytes. Although
Fig. 3. Cherax quadricarinatus. Midgut-associated glands, possibly for the secretion of the peritrophic membrane, of a moribund crayfish stained with the DIGlabeled gene probe for SMV. Many nuclei give a strong positive probe reaction (black in the photomicrograph). Scale bar $=2 \mu \mathrm{m}$
Fig. 4. Cherax quadricarinatus. Seminal ducts of a moribund male crayfish stained with the DIG-labeled gene probe for SMV. Many epithelial cell nuclei show a strong positive probe reaction (black) while the sperm cells (quite small and difficult to resolve in this photomicrograph) were negative. Scale bar $=69 \mu \mathrm{m}$

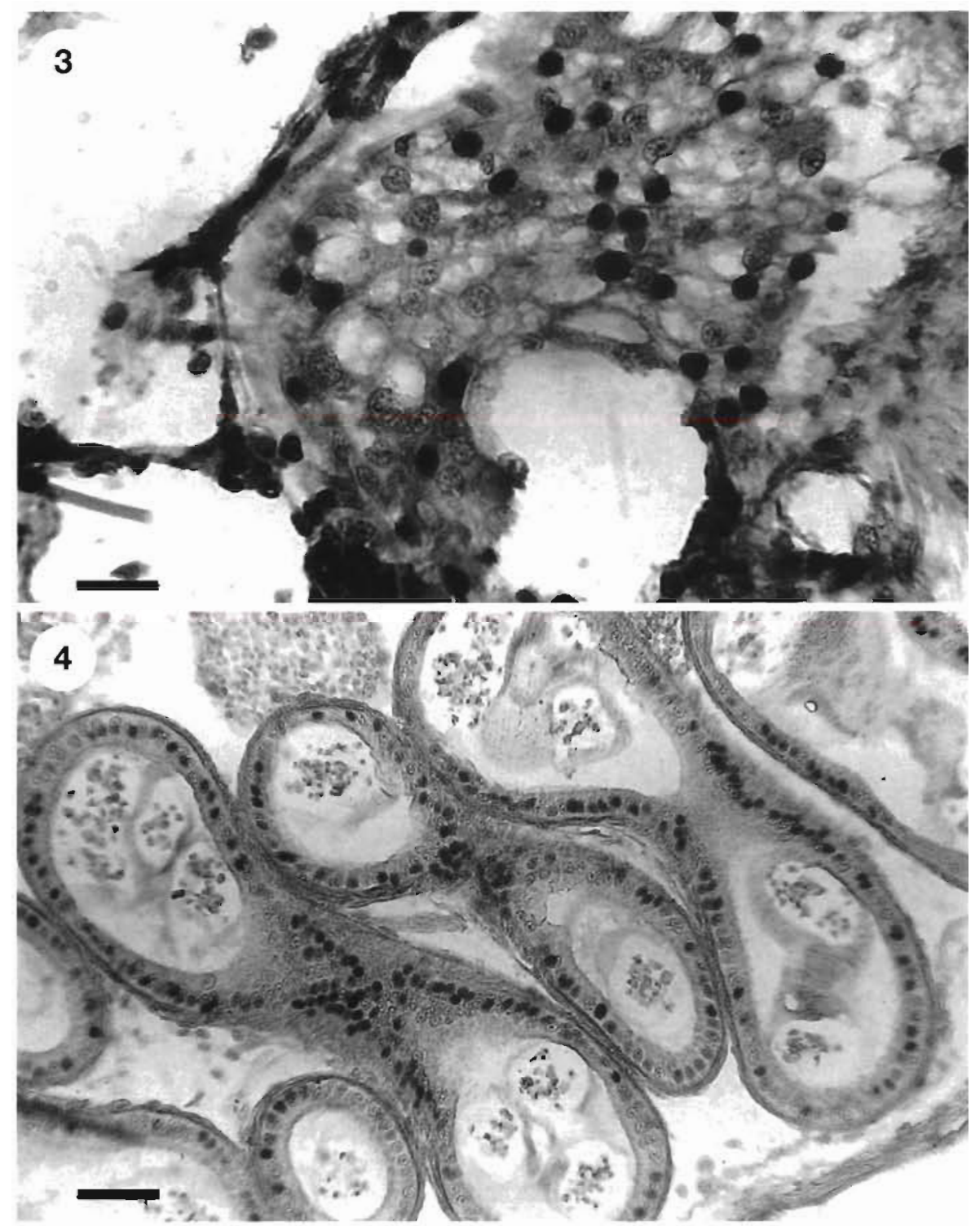



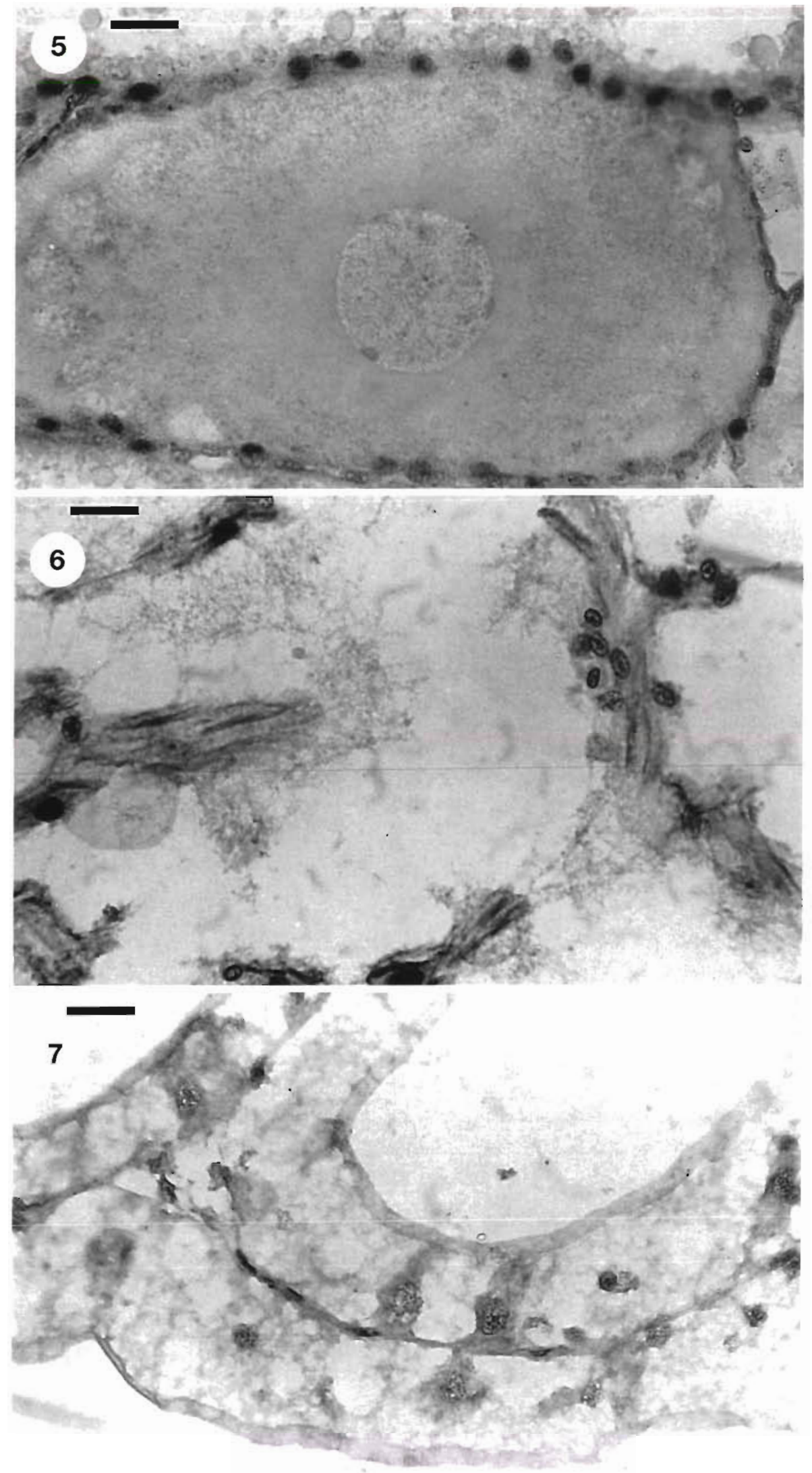

Fig. 5. Cherax quadricarinatus. Ovary tissue from moribund crayfish stained with the DIG-labeled gene probe for SMV. Follicle cells surrounding this oocyte give a positive probe reaction while the nucleus of the oocyte is negative. Scale bar $=25 \mu \mathrm{m}$

Fig. 6. Cherax quadricarinatus. Heart tissue of moribund crayfish stained with the DIG-labeled gene probe for SMV. Some of the myonuclei show positive probe reactions (black in the photomicrograph). Scale bar $=33 \mu \mathrm{m}$

Fig. 7. Cherax quadricarinatus. Hepatopancreas of a healthy crayfish obtained from the same farm as the moribund crayfish depicted above and stained with the DIGlabeled gene probe for SMV. No probe positive cells were seen. Scale bar $=20 \mu \mathrm{m}$ 
staining was intense and extensive in moribund crayfish, cytolysis of the infected cells was not evident at the level of light microscopy. Seventy-five percent $(9 / 12)$ of the crayfish were probe positive. Signals ranged from strong and extensive to very localised or weak. Two crayfish from a pond that was still producing well gave totally negative reactions to the SMV gene probe (Fig. 7).

Discussion. The total lack of external clinical signs, and the failure to identify known, life-threatening pathogens in moribund crayfish was reminiscent of broodstock prawns that had died in the hatchery of SMV (Fraser \& Owens 1996). The scenario also resembled the presentation of prawn mid crop mortality syndrome, which is a mixture of SMV (Owens et al. 1998) and other pathogens, particularly, gill-associated virus (Spann et al. 1997). It was this similarity which led to the application of the SMV gene probe to these crayfish samples for possible identification of a causative agent. It is this indiscernible nature of SMV by gross signs and normal light microscopy that is almost its pathognomonic trademark. Although other problems undoubtedly exist in crayfish farms and although it is dangerous to extrapolate from probable cause on a single farm to the whole industry, our results suggest that a much more extensive and thorough investigation is needed regarding the current role of SMV in crayfish farm problems.

The infection of crayfish with a virus that had only been previously found in prawns has major implications. Certainly, white spot syndrome virus (WSSV) and yellow head virus have multiple crustacean hosts. In the case of WSSV, prawns and freshwater crayfish are known hosts (Wang et al. 1999), paralleling the current situation. It is not known whether the SMV has transferred from prawns to crayfish or from crayfish to prawns. Perhaps, SMV has always been in both species. Only further research can clarify this. Australia has many other valuable crayfish species that might be vulnerable to this virus and their susceptibility should be investigated. Similarly, aquaculturalists in Australia have exported thousands of live Cherax quadricarinatus juveniles around the world to countries like China, Ecuador, USA and Tahiti and their status with regard to pathogens was largely unknown. We suggest that the carrier status of $C$. quadricarinatus for known viruses and pathogenic rickettsia be determined before any further translocations occur.

Editorial responsibility: Timothy Flegel,

Bangkok, Thailand
Acknowledgements. This research was funded by a Fisheries Research and Development Corporation grant, 96/301 and James Cook University.

\section{LITERATURE CITED}

Bell TA, Lightner DV (1988) A handbook of normal penaeid shrimp histology. World Aquaculture Society, Baton Rouge

Culling CFA, Allison RT, Barr WT (1985) Cellular pathology techniques, 4 th edn. Butterworths, London

Durand S, Lightner DV, Nunan LM, Redman RM, Mari J, Bonami J (1996) Application of gene probes as diagnostic tools for white spot baculovirus (WSBV) of penaeid shrimp. Dis Aquat Org 27:59-66

Edgerton B, Owens L (1999) Histopathological surveys of the redclaw freshwater crayfish Cherax quadricarinatus in Australia. Aquaculture 180:23-40

Edgerton B, Owens L, Glasson B, De Beer S (1994) A small double stranded RNA virus from Cherax quadricarinatus. Dis Aquat Org 18:63-69

Edgerton B, Owens L, Harris L, Thomas A, Wingfield M (1995) A health survey of farmed redclaw crayfish, Cherax quadricarinatus (von Martens) in tropical Australia. Proc Astacol Soc 10:322-338

Fraser C, Owens L (1996) Spawner-isolated mortality virus from Australian Penaeus monodon. Dis Aquat Org 27: $141-148$

O'Sullivan D (1998) Status of Australian aquaculture in 1996/97. Austasia Aquaculture Trade Directory, Turtle Press, Rosny, Tasmania, p 14-26

Owens L, Edgerton B (1997) A review of recent information on diseases of freshwater crayfish. In: Flegel TW, McRae IH (eds) Diseases in Asian aquaculture III. Fish Health Section, Asian Fisheries Society, Manila, Philippines, p 219-224

Owens L, Haqshenas G, McElnea C, Coelen R (1998) Putative spawner-isolated mortality virus associated with mid-crop mortality syndrome in farmed Penaeus monodon from northern Australia. Dis Aquat Org 34:177-185

Rolighed J, Lindeberg H (1996) Detection of HPV 11 DNA in paraffin embedded laryngeal tissue with a DIG-labeled DNA probe. Non-radioactive in situ hybridization application manual, 2nd edn. Boehringer-Mannheim, Mannheim, p $122-125$

Spann KM, Cowley JA, Walker PJ, Lester RGJ (1997) A yellow-head-like virus from Penaeus monodon cultured in Australia. Dis Aquat Org 31:169-179

Tan CK (1998) The characterisation of Rickettsiales isolated from Cherax quadricaninatus. BSc(Hons) thesis, Department of Microbiology and Immunology, James Cook University, Townsville

Wang Q, White BL, Redman RM, Lightner DV (1999) Per os challenge of Litopenaeus vannamei postlarvae and Farfantepenaeus duorarum juveniles with six geographic isolates of white spot syndrome virus. Aquaculture 170: 179-194

Submitted: October 1, 1998; Accepted: January 10, 2000 Proofs received from author(s): March 6, 2000 